\title{
Students' Perceptions on the Application of Standardized English Language Proficiency Test as Graduation Requirement in Tourism Higher Education in Indonesia (A Case Study at Trisakti School of Tourism)
}

\author{
Nurti Rahayu \\ Sekolah Tinggi Pariwisata Trisakti \\ nurti@stptrisakti.ac.id
}

\begin{abstract}
The growing importance of English competence in various industries is one of the pull factors of the increasing need of English Language Proficiency (ELP) for university graduates. One of the ways to motivate students' English competence is to set English language proficiency as graduation benchmark. This study aims to describe students' perspectives on such policy and how it affects the students' learning. A descriptive qualitative research is employed. A questionnaire is used to gain the primary data. The research participants are students of Trisakti School of tourism who has experienced such policy. The questionnaires comprise of two parts: demographic data and questions of students' perceptions on various aspects on the usage of English language proficiency tests. Students' perception on various campus program to improve English competence is also asked. The results reveal that students are familiar with the international standardized tests such as TOEIC, TOEFL and IELTS and they do make various preparation for the tests. As much as $60 \%$ of the respondents agree with the campus policy to set TOEIC and TOEFL score for graduation requirements. As for students' perception on campus program, the results reveal that awarding scholarship for the top achiever students and live in program in English speaking program are considered to be the most effective program. The least effective programs are class grouping based on test score. The results can be of a valuable source for policy makers in the institution to develop a more effective program ti improve the students' English competence.
\end{abstract}

Keywords : Perceptions, English Language Proficiency Test, Graduation Requirement, Higher Education 
Students' Perceptions on the Application of Standardized English Language Proficiency Test as Graduation Requirements in Tourism Higher Education in Indonesia

(A Case Study at Trisakti School of Tourism)

\section{A. Introduction}

Compared with other countries, English proficiency in Indonesia is relatively low. A survey measuring English Proficiency Index puts Indonesia's rank 51 with 51.58 score, lower than Pakistan. In Asia, Indonesia ranks 13; slightly better than Sri Lanka, while the Asian top five belongs to Singapore (68.63), Philippines (61.84), Malaysia (59.32), India (57.13), and Hong Kong (56.38).(English First, 2018). The low English proficiency partly contributes to global human capital index which puts Indonesia just slightly above average with 80 out of 130 countries being surveyed. (WEF, 2017) It is also said in the World Economic Forum (WEF) Survey that Vietnam and Indonesia have made remarkable progress in educational attainment among their younger generations and have a correspondingly solid outlook for building their future human capital potential across the Development sub index. In another survey released by United Nation Development Program (UNDP), the human development index in Indonesia ranks 115 out of 189 countries making Indonesia belong to the medium human development together with Vietnam in 116 rank.(UNDP, 2018).

With the growing importance of English competence in various industries along with the implementation of ASEAN Economic Society allowing free flow of labor workers across countries, there is a growing need of English Language Proficiency (ELP) for university graduates. In order to meet this demand, higher education institution start to set a standardized English Language Proficiency Test as graduation benchmark. Various English standardized tests are adopted either international tests such as TOEFL, TOEIC or IELTS or local test such as GEPT, TOEP, EIKEN, etc. Students in various countries are required to pass certain range of score of these tests as one of graduation requirements.

In Taiwan, the General English Proficiency Test (GEPT) is developed and implemented to assess the general English proficiency of EFL learners in order to encourage the general study of English. (Tsai \& Tsou, 2009)(C.-M. Shih, 2013) Minister of Education has required graduates to pass the GEPT at certain level; before they awarded diploma.(Wu, 2012) Meanwhile, with the largest English language learners, department of Higher Education of the Chinese Ministry on Education require the students of all academic disciplines to take College English Test (CET) (Qian \& Cumming, 2017). In addition, 46 universities in Japan uses English Test Score from EIKEN, TOEFL and TOEIC as credit awarding policies. (In'nami \& Koizumi, 2017)

Research in this area focusing on the teachers' and students' perspectives toward proficiency test as graduation benchmark (Vongpumivitch, 2012), (Tsai \& Tsou, 2009) on interface on the adoption of high stake testing with students' learning motivation reveals whether and how classroom tests motivated students' effort. (Huang, 2012).

Test washback dated from (Vernon in C. M. Shih, 2010) stating that tests serve as extraneous incentives for encouraging students to learn. The issue of test washback and language learning has also been viewed to have positive or 
Students' Perceptions on the Application of Standardized English Language Proficiency Test as Graduation Requirements in Tourism Higher Education in Indonesia

(A Case Study at Trisakti School of Tourism)

detrimental washback, (Liying Cheng, Yoshinori Watanabe, 2004), (Alderson \& Wall, 1993), or said to have deleterious effect on teaching and learning. (Popham in (C. M. Shih, 2010) and the validity of the test (Messick, 1996). Further research reveals the possible washback of test policy implementation in the area of social and educational, school, parental and student factors need to be taken into account prior to the policy implementation. (C. M. Shih, 2010).

Despite the abundant research on the teachers' and students' perspectives on ELP tests and the washback of the adoption of ELP tests as graduation benchmark in various countries, very few studies have examined the adoption of such policy in higher education in Indonesia. This research aims to investigate the factors affecting universities whether or not to apply this policy. The researcher also seeks to explore the washback of such policy viewed from students and parents, school factors, and HRD managers. This research needs to prove whether or not test score benchmark affects students learning motivation. In addition, the results are hopefully able to prove the effects of ELP test for various stakeholders. This study is significant in that it may reveal college's dilemma to equip their students with international language certification regarding their higher test fee. At the same time, it will reveal how recruiters and other stakeholders view the certification as one of the documents needed for staff selection and promotion. The research design is descriptive qualitative. The research aims to find out students' previous experience of English standardized tests and their perceptions toward English standardized test in tourism higher institution. As for the research location, it focuses on Trisakti School of Tourism as this is relevant with the discussion. Previous research conducted in this campus focuses on the benefits of students' participations in campus organizations for professional and working experience by (Nigrum \& Azalia, 2018), students' self-reflections on the benefits of Service Learning Program (Rahayu, Tarigan, \& Sinaga, 2016), and

\section{B. Research Methodology}

This research is descriptive qualitative with questionnaires to gain the primary data. Secondary data is taken from library research. The questionnaires consist of demographics and perceptions on English standardized tests. Having composed the questions, they are validated by several students to check the content and dictions so that they are not ambiguous. Then, the questionnaires are typed in a Google form to be conveniently distributed to all students. After a few weeks, 78 responds were collected and analyzed. The research was conducted at Trisakti School of Tourism with the first grade students as sample. The English standardized tests refer to IELTS, TOEIC and TOEFL as they are the two tests which are used in the institution. 
Students' Perceptions on the Application of Standardized English Language Proficiency Test as Graduation Requirements in Tourism Higher Education in Indonesia

(A Case Study at Trisakti School of Tourism)

\section{Review of Related Theory}

\section{Trisakti School of Tourism at a Glance}

Cited from its official website, Trisakti School of Tourism (STP) was established on June 2, 1969 under the name of the Trisakti Hospitality \& Tourism Academy, for the idea of Mr. Mulyatno Sindhudarmoko, SE., Dean of the Faculty of Economics, Trisakti University. Furthermore, Mr. Mulyatno Sindhudarmoko, SE., Aas appointed by the Trisakti Foundation to become the Director of the Trisakti Hospitality \& Tourism Academy from November 26, 1969 to 1990.

In 1972, the Trisakti Hospitality \& Tourism Academy opened a new department namely Tour \& Travel. The Trisakti Hospitality and Tourism Academy was later converted to the Trisakti Tourism Academy according to Government regulations. In 1985, he began taking part in the Bachelor of State Examination held by Kopertis Region III.

In 1987, the Trisakti Tourism Academy from Campus A Kyai Tapa Grogol then moved to occupy its new campus on IKPN, Tanah Kusir, Bintaro. Building A new campus of the Trisakti Tourism Academy was honored by its opening by the Minister of Tourism, Post and Telecommunications at the time, Mr. Soesilo Soedarman on December 3, 1988. Another important event, June 21, 1989, the Trisakti Tourism Academy obtained the status of "SAVED" based on Minister of Education and Culture Decree No: 383 / O / 1989, while Building B of the Trisakti Tourism Academy campus was completed and inaugurated by the Minister of Education and Culture, Prof. Dr. Ing. Wardiman Djojonegoro on April 10, 1997.

In 1999, the Trisakti Tourism Academy changed its name and status to Trisakti Tourism School based on the Decree of the Minister of Education and Culture of the Republic of Inconductedsia No: 102 / D / O / 1999 dated June 15, 1999. The name change was because since then the Trisakti Tourism School held Diploma IV education in addition to Diploma III education for Hospitality and Tourism Business majors. In 2001, the Trisakti College of Tourism also opened the Diploma I education level with the Hospitality Department having a specialization field, namely the Room and Administrative Division and the Travel Business Department having specialization areas, namely the Tariff of Pasasi and Scout Documents.

The Vision of this institution is to become a Qualified Global College of Tourism and Commodity Center (Center of Excellence) development of tourism and hospitality Sciences. While the mission is to realize the goals - the vision as defined in the above, four (4) Main Mission will be borne by the Trisakti School of Tourism as higher education institutions, namely:

a. Organizing Higher Education in tourism and hospitality professionals sustainable international level (High Professionalism and Sustainability), to produce the Human Resources Quality and competitive (High Performance and Competitiveness); 
Students' Perceptions on the Application of Standardized English Language Proficiency Test as Graduation Requirements in Tourism Higher Education in Indonesia

(A Case Study at Trisakti School of Tourism)

b. Discover new things Sciences Sector tourism and hospitality (Innovation in Hospitality and Tourism);

c. Uphold the dignity and human values in accordance with the values of Trisakti sound nationality (High Brand Image and Unity);

d. Expanding access and networking to support the development of national and international collaboration (High Access and Networking).

The aim of this institution is:

a. Developing Trisakti School of Tourism position as international colleges in the mastery of professional competence and knowledge of tourism by establishing a curriculum that is always adapted to the development of science, knowledge, technology and art are sustainable and environmentally friendly and relevant to the needs and demands of the times;

b. Implement academic and professional education to form and produce graduates who are faithful and devoted to God Almighty, be honest and fair, character wise leadership, vision of national unity and humanity, innovative, independent, entrepreneurial, able to participate in the international forum and excel in academic and professional capability in the disciplines of Tourism;

c. Develop a program enhancement percentage of students with priority planning policies (including increasing the number and quality of students through the recruitment of prospective students proactively air quality and improving the quality and relevance of skills / program prioritization studies);

d. Develop multidisciplinary research program to accelerate growth in the improvement of IPR protection with the policy of phasing (first increase the number of researchers involved, and secondly to improve the quality of research);

e. Developing a quality improvement program of community service focuses on community empowerment and increased participation of the international community with the policy of increasing awareness and empathy in helping and empowering people so that the experience and expertise gained can be a lesson for the nation and the international

f. Organizing the learning process productive, effective and efficient, providing optimal educational services and evenly and create a conducive climate and academic culture in accordance with the guidelines for Trisakti value;

g. Do coaching students and alumni of integrated and sustainable to foster a culture of pride and love of alma mater and cooperation among students, alumni and academicians;

h. Maintaining and developing cooperation and mutual institutional partnerships provide added value in the field of higher education with higher education institutions, industry and the public both at home and abroad;

i. Maintaining continuity (sustainability) Trisakti School of Tourism to improve resource management and quality of education to be productive, professional, 
Students' Perceptions on the Application of Standardized English Language Proficiency Test as Graduation Requirements in Tourism Higher Education in Indonesia

(A Case Study at Trisakti School of Tourism)

effective, efficient, meet national and international standards and to increase the autonomy of the establishment responsible for the successful achievement of objectives Trisakti School of Tourism optimally.

\section{Testing Impacts}

Testing is now becoming crucial parts in education The growing importance of tests lead to testing as big business (Spolsky in Ginther \& McIntosh, 2018). Furthermore, high stakes testing is often correlated with consequences either positive or negative. The consequences are better called as 'impact' or 'washbacks.

Hall \& Lew in (Vitriani et al, 2017) defines Impact as a change (environmental, economic and social change) in a given circumstance and time as a result of external stimulus. Wall in (Ginther \& McIntosh, 2018) defines impact as "any of the effects that a test may have on individuals, policies or practices, within the classroom, the school, the educational system or society as a whole". She also points out that "washback (also known as backwash) is sometimes used as a synonym of impact, but it is more frequently used to refer to the effects of tests on teaching and learning" at the classroom level. Many language testers these days consider washback as a dimension of impact. 'Washback' is one of a set of terms that have been used in general education, language education and language testing to refer to a set of beliefs about the relationship between testing and teaching and learning (Hamp-Lyons, 1997)

The impact of testing in teaching and learning is also associated with the issue of validity. (Messick, 1996) He further states that a test might influence what is taught but not how it is taught, might influence teacher behaviors but not learner behaviors, or might influence both with little or no improvement in skills. Hence, washback is a consequence of testing that bears on validity only if it can be evidentially shown to be an effect of the test and not of other forces operative on the educational scene.

\section{Results and Discussions}

\section{The Research Results}

The results are based on the analysis of the questionnaires comprising of demographic and perceptions.

\section{Demographic Data}

The demographic data consists of the background information of the respondents such as department, age, gender. The data reveals that $61,8 \%$ from D4 Hotel, 23\% from D4 UPW, 11,8\% from S1 Hospitality and tourism, and 2,7\% from D3 Hotel. As for the age, 69\% aged 21-22 years old, another $24 \%$ aged $19-20$ and then $7 \%$ aged 23 or more. Most participants are female with $67 \%$ and $33 \%$ is male. 
Students' Perceptions on the Application of Standardized English Language Proficiency Test as Graduation Requirements in Tourism Higher Education in Indonesia

(A Case Study at Trisakti School of Tourism)

\section{Students Perceptions on English Standardized Tests}

Eleven questions are administered to reveal the students' perceptions on English standardized tests. The discussions are based on the students' response.

\subsection{Have you ever taken English tests except for campus program?}

The survey reveals that as much as $51.3 \%$ has ever taken English Proficiency test and another 48.7\% hasn't experienced any English test before. This implies that almost half of the participants have no previous experience on any tests since the students derive from 34 provinces in Indonesia with varied English ability.

\subsection{What was your last TOEIC (prediction) score?}

The participants mention that their score belong to intermediate $(30 \%)$, basic working proficiency (29\%), advanced working proficiency (18\%), and elementary proficiency $18 \%$, the rest $(5 \%)$ belong to novice learners.

\subsection{What was your last TOEFL (prediction) score?}

The results show that $37 \%$ of participants haven't taken TOEFL test before, $18 \%$ got 505-600, 17\% got 400-500,12\% got less than 400 and $12 \%$ forgot their score. And the other 4\% admits the score to be higher than 600 .

\subsection{What was your last IELTS (prediction) score?}

As for IELTS test, the result shows that $81 \%$ never take the test before, and $19 \%$ got average score of 5 or more.

\subsection{What did you do to prepare for the tests?}

As the campus cite regular tests for its students, this question seeks to find out students' preparation before the test as the following: 59\% reads some books and listen to English program on various media, 13\% read and do some practice books, $7 \%$ join course somewhere, 4\% join in campus English course. The other $16 \%$ have various ways to prepare for the course such as downloading practice tests from their gadget, watching Youtube, etc. Only 1\% is said to have no preparation. From the data above, it can be said that students take the test seriously seeing from their preparation.

2.6 Do you agree with the campus policy to cite standard score as graduation benchmark?

Given such question, $60.5 \%$ agree on the campus policy, and the other $39.5 \%$ on that due to various reasons below. It is a good news regarding the fact that all campus policy should be supported by all stakeholders such as students.

\subsection{If you agree, why?}

The students who agree with the campus policy mention that standardized test score is able to improve the competitiveness and college enrollment (33\%), to enhance the English language competence (24\%), to provide wider opportunity to study and work abroad (13\%), to improve the overall human resource quality (20\%), and to boost learning motivation (11\%). 
Students' Perceptions on the Application of Standardized English Language Proficiency Test as Graduation Requirements in Tourism Higher Education in Indonesia

(A Case Study at Trisakti School of Tourism)

\subsection{If you disagree, why?}

The students who did not agree mentions that the policy is leading to testing based learning (44\%), such test is costly (24\%), reduce their time to learn vocational skills $(15 \%)$, not sure to pass such tests $(12 \%)$. The other $5 \%$ states that they are not interested to learn English and English will not be beneficial for their future career.

2.9 How confident are you to pass the 450 standard score in the second semester?

When asked about their confidence in passing the standard score, $58 \%$ is confident to pass, $10 \%$ said they are not sure to pass the standard. The other $32 \%$ said they might pass the standard score. It means that about half of the participants are not sure about their English competence to pass the standard score.

\subsection{Are you interested to learn English?}

The students stated that $43 \%$ is very interested to learn, 39 is interested, $16 \%$ somewhat interested, and 3\% is not interested. It shows that around $82 \%$ is interested to learn English as in tourism, they have to address people from all over the globe, and English is such media to work with.

2.11 How effective are these programs to improve students' competence in English?

This question is to reveal students 'perception on the various programs conducted by the language center which is in line with academic division. Below are some proposed ways, some of them have been conducted and the rest are not yet applied. Research participants are to choose 5 options: very effective, effective, neutral, ineffective, and very ineffective. The frequencies are presented in percentage. The program is listed below:

1. Campus policy to cite standard score as graduation benchmark.

2. Compulsory Remedial Test for students' with below standard score

3. English Preparation Class before taking TOEFL/TOEIC tests?

4. Scholarship award for top scorer

5. Free journal access in the library

6. Counselling session for the low English achievers

7. Taking part in English Club

8. Class Grouping based on Test Score

9. English Class with Independent Assignment

10. Attending TOEIC/TOEFL prediction test

11. Taking part in summer camps or homestay with English as medium of communication

12. Attending study tour in English speaking countries

13. English as medium of instruction for all subjects

14. Requiring minimal English test score to register at Trisakti School of Tourism. 
Students' Perceptions on the Application of Standardized English Language Proficiency Test as Graduation Requirements in Tourism Higher Education in Indonesia

(A Case Study at Trisakti School of Tourism)

Tabel 1. Perceptions of Proposed Program

\begin{tabular}{|l|l|l|l|l|l|l|}
\hline NO PROGRAM & VERY EFFECTIVE & EFFECTIVE & NEUTRAL & INEFFECTIVE & VERY INEFFECTIVE & TOTAL \\
\hline 1 & $13 \%$ & $43 \%$ & $14 \%$ & $26 \%$ & $4 \%$ & $100 \%$ \\
\hline 2 & $17 \%$ & $47 \%$ & $27 \%$ & $5 \%$ & $4 \%$ & $100 \%$ \\
\hline 3 & $27 \%$ & $50 \%$ & $17 \%$ & $6 \%$ & 0 & $100 \%$ \\
\hline 4 & $35 \%$ & $43 \%$ & $17 \%$ & $2 \%$ & $3 \%$ & $100 \%$ \\
\hline 5 & $25 \%$ & $47 \%$ & $21 \%$ & $5 \%$ & $2 \%$ & $100 \%$ \\
\hline 6 & $34 \%$ & $51 \%$ & $11 \%$ & $4 \%$ & $0 \%$ & $100 \%$ \\
\hline 7 & $9 \%$ & $31 \%$ & $52 \%$ & $6 \%$ & $2 \%$ & $100 \%$ \\
\hline 8 & $8 \%$ & $30 \%$ & $27 \%$ & $21 \%$ & $14 \%$ & $100 \%$ \\
\hline 10 & $12 \%$ & $44 \%$ & $31 \%$ & $9 \%$ & $4 \%$ & $100 \%$ \\
\hline 11 & $14 \%$ & $60 \%$ & $17 \%$ & $9 \%$ & 0 & $100 \%$ \\
\hline 12 & $21 \%$ & $47 \%$ & $26 \%$ & $6 \%$ & 0 & $100 \%$ \\
\hline 13 & $35 \%$ & $51 \%$ & $11 \%$ & $3 \%$ & 0 & $100 \%$ \\
\hline 14 & $16 \%$ & $39 \%$ & $25 \%$ & $18 \%$ & $2 \%$ & $100 \%$ \\
\hline
\end{tabular}

From the table above, it can be summarized that the most effective program with $35 \%$ each is program no. 4 and 12 . The program is scholarship award for top scorer and attending study tour in English speaking countries. Beside that program no 6 also gain 34\%, the program is counselling session for the low English achievers. It can be seen that appreciation is needed for the top scorer in the form of scholarship and study tour abroad. While for the low achiever, they still need some counselling and learning guidance so that they can keep up with their friends.

As for some programs which are not effectives are program number 8 , Class Grouping based on Test Score. The participants think that grouping the class based on score ranks is either ineffective or very ineffective. The other program is number 1, campus policy to cite standard score as graduation benchmark. This policy usually gains pro and cons wherever applied regarding the test washbacks. The pro says that test is another way to motivate the students' learning, but the cons say that test has nothing to do with learning. Moreover, high stakes testing in higher education usually puts more pressure on students' learning. In addition, a program on using English as medium of instruction for all subjects and English requirement to register at Trisakti School of Tourism are considered ineffective.

\section{Research Discussion}

There are various considerations on the implementation of English standardized test for graduation requirements. Before it was set as a campus 
Students' Perceptions on the Application of Standardized English Language Proficiency Test as Graduation Requirements in Tourism Higher Education in Indonesia

(A Case Study at Trisakti School of Tourism)

policy, the top management in the institutions believe that they should equip the students with skills, competence and knowledge to win the global work competition. English standardized tests such as TOEFL and TOEIC are viewed to be some of the must-have certificates as they are widely required by government institution, educational and industry for recruitment processes. Along with the implementation of East ASEAN Community which allows free flow of labor, there comes high demand on skilled staffs with international language competence. To do this, the industry set specific test score for recruitments. In this case, failing to meet the score standards means failing to pass the first career entrance. In this case, the higher the students' score, the more work opportunities they will have in the industry which is not limited to local but also overseas work. In the contrary, students with limited score will also have limited chance to works.

Another consideration is based on the higher education accreditation standard. Since all state and private higher education shall go to regular accreditation by the government, they are competing to file their teaching learning process, and test assessment to make sure that the process runs as expected. International certifications belong to some assessment with significant score for accreditation. The more students taking international standardized tests, the better the accreditation score will be.

A possible reason on the implementation of this policy is regarding with the teaching-learning strategy. Millennials need strong reason and encouragement to do something. Since TOEFL and TOEIC are not taught in classrooms as part of curriculum, there should be a policy to encourage students to maximize their English ability so that they can meet the required score. Those who do meet the standard are required to take test preparation courses outside the classroom schedules. If not, they are not allowed to take English subjects in the curriculum. As a follow-up policy, students need to meet specific score in order to register for thesis examination, if not, they need to retake the test again. In this case, the policy set by the institution serves as external motivation to improve students' English ability.

This study seeks to describe students' view on such policy. In general, students enrolling in tourism higher education agree on the importance of English language ability to facilitate international communication during their trainings and future careers. Most of the students are familiar with TOEFL, TOEIC, and IELTS. The latter is less popular than the others. It means that they come to acquaintance with the tests during their secondary schools. Those who study at vocational school used to take TOEIC tests while TOEFL is introduced at Senior High School. Interviews with some students reveal that those who resides outside Java, such as in the eastern part of Indonesia are not well-familiar with those tests. However, a group of students from Papua have taken IELTS test since the local government send them to a IELTS preparation class for free. This implies that local government concerns more on students English language 
Students' Perceptions on the Application of Standardized English Language Proficiency Test as Graduation Requirements in Tourism Higher Education in Indonesia

(A Case Study at Trisakti School of Tourism)

certification. Given such background, students with previous exposure on International English assessment finds no obstacle to meet the institution standards score.

On the other hands, the results reveal around one third of the students without prior exposure on language tests. With limited English ability, they need to struggle more to achieve the standards. The low achiever students might have limited English skills since they have low motivation, unavailability of competent English teachers, or they might have wrong learning methods due to the frequent use of transtool in their gadget and it prevents them from developing basic stock of vocabulary.

To cope with those low achievers, the campus utilized English standardized tests as graduation requirements to motivate the students to upgrade their ability. Those students will go into two-semester courses to enrich their basic English and test preparation class. Those courses as crucial as they provide basic foundation of English and test taking strategy. Upon completing the courses, students are taking English for Specific Purposes subject such as English for Hotel, English for restaurant, business English, etc. Those subjects are based on functional syllabus when students are required/respond to specific function/ situation in the workplace. Those functions require students to appropriate vocabulary stock and good speaking skills, if not, they will not pass the tests. The application of such policy serves as motivational strategy for those students in spite of the facts that high-stake testing brings about various washback.

The washback is seen from the teaching methods. Teachers tend to teaching for testing, thus the process is dominated by drilling various types of questions and some tips how to succeed the tests. Also, not all students are motivated by the policy, some of them think that they go to hotel school to improve their cooking skills which has nothing to do with English standardized tests. In this case, they are not motivated to learn. Students also see that those standardized tests are usually very costly.

Regarding the proposed program to increase students' English competence, students see live-in or study tour program in English speaking countries to both very effective and effective $86 \%$, while conducting counselling program for low achievers get $85 \%$. The results imply students' preference as practical way of learning English is by living in the country where the language is spoken. In the near future, the institution shall respond by providing live-in program in those country regarding the facts that the international program offers study program in Thailand, Korea, China, and Switzerland where English is not the mother tongue. Of course, this policy can be integrated by establishing MOU with some related institutions where English is spoken such as Australia. As with the second perceptions, counselling for low achiever students is performed in English Club as one of students' organization. The peer counselling is intended for high achiever students to assist the low achiever by 
Students' Perceptions on the Application of Standardized English Language Proficiency Test as Graduation Requirements in Tourism Higher Education in Indonesia

(A Case Study at Trisakti School of Tourism)

continuous guidance on their English. The obstacle comes from the students who are reluctant to register this program.

The programs of using English as medium of instruction for all subjects (13) and setting minimal English test score to register at Trisakti School of Tourism (14) gains minimum support with the percentage is $40 \%$ and $38 \%$ respectively. When asking about the policy on using test score as graduation requirements, the percentage is $56 \%$. This shows students' mostly agree on the importance of international test score to increase students' competitiveness in the future careers.

\section{E.Conclusion}

From the discussion below, it can be summarized as the following:

1. Half of the participants of the research has no previous exposure of English standardized tests. They mostly know about test such as TOEFL, TOEIC and IELTS from the college.

2. Almost half of the participants who has taken English tests belong to lower intermediate ability. TOEIC and TOEFL are more popular than IELTS, it can be seen that only few students ever took the IELTS tests.

3. Most of the students realize the importance of English competence, that is why they agree with the campus policy to set English test score as graduation benchmark. Those who did not agree mostly due to the reasons that they dislike learning based test, and assume that such tests are usually costly.

4. Most of the students are confident that they can pass the 450 score for the second semester. The rest are not sure to pass the standard. Only $10 \%$ is not confident to pass the score.

The program to improve the English competence is awarding scholarship for top scorer and more study tour program in English speaking countries to experience live-in with the host. Counselling for low achievers is said to be very effective. On the other hands, grouping the class based on the score and adopting English score for graduation benchmark, English as medium of instruction for all subjects, and English requirement to register at Trisakti School of Tourism are considered to be ineffective. 
Students' Perceptions on the Application of Standardized English Language Proficiency Test as Graduation Requirements in Tourism Higher Education in Indonesia

(A Case Study at Trisakti School of Tourism)

\section{REFERENCES}

Alderson, J. C., \& Wall, D. (1993). Does washback exist? Applied Linguistics, 14(2), 115-129. https://doi.org/10.1093/applin/14.2.115

English First. (2018). EF English Proficiency Index 2018.

Ginther, A., \& McIntosh, K. (2018). Language Testing and Assessment. The Palgrave Handbook of Applied Linguistics Research Methodology, 845-867. https://doi.org/10.1057/978-1-137-59900-1_39

Hamp-Lyons, L. (1997). Washback, impact and validity: Ethical concerns. Language Testing, 14(3), 295-303. https://doi.org/10.1177/026553229701400306

Huang, S. C. (2012). Pushing learners to work through tests and marks: Motivating or demotivating? A case in a Taiwanese university. Language $\begin{array}{lll}\text { Assessment } \quad \text { Quarterly, } & \text { 9(1), }\end{array}$ https://doi.org/10.1080/15434303.2010.510898

In'nami, Y., \& Koizumi, R. (2017). Using EIKEN, TOEFL, and TOEIC to Award EFL Course Credits in Japanese Universities. Language Assessment Quarterly, 14(3), 274-293. https:/ / doi.org/10.1080/15434303.2016.1262375

Liying Cheng, Yoshinori Watanabe, A. C. (2004). Washback in Language Testing. New Jersey: Lawrence Erlbaum Associates, Inc., Publishers.

Messick, S. (1996). Validity and washback in language testing. Language Testing, 13(3), 241-256. https://doi.org/10.1177/026553229601300302

Nigrum, L., \& Azalia, M. (2018). Benefits of Participation in Student Organization in Tourism Education : Professional and Working Opportunities Through Experience. Tourism Research Journal, 2(1), 1-14.

Qian, D. D., \& Cumming, A. (2017). Researching English Language Assessment in China: Focusing on High-Stakes Testing. Language Assessment Quarterly, 14(2), 97-100. https:// doi.org/10.1080/15434303.2017.1295969

Rahayu, N., Tarigan, E., \& Sinaga, D. C. (2016). Students' Self Reflection On Service Learni ng Program Nurti Rahayu,et al STUDENTS' SELF REFLECTION ON SERVICE LEARNING PROGRAM (A Case Study of Service Learning Program at Trisakti School of Tourism). ICTTE UNS Conference Proceedings, 2(1), 540-552.

Shih, C.-M. (2013). The General English Proficiency Test. Language Assessment Quarterly, 5(1), 63-76. https://doi.org/10.1080/15434300701776377Shih, C. M. (2010). The washback of the general English proficiency test on university policies: A Taiwan case study. Language Assessment Quarterly, 7(3), 234-254. https://doi.org/10.1080/15434301003664196

Tsai, Y., \& Tsou, C. (2009). A standardised English Language Proficiency test as the graduation benchmark: student perspectives on its application in higher education. Assessment in Education: Principles, Policy \& Practice, 16(3), 319-330. https://doi.org/10.1080/09695940903319711 
Students' Perceptions on the Application of Standardized English Language Proficiency Test as Graduation Requirements in Tourism Higher Education in Indonesia (A Case Study at Trisakti School of Tourism)

UNDP. (2018). Human Development Indices and Indicators. 2018 Statistical Update. United Nations Development Programme, 27(4), 123.

Vongpumivitch, V. (2012). Motivating lifelong learning of English? Test takers' perceptions of the success of the general English proficiency test. Language Assessment Quarterly, 9(1), 26-59. https://doi.org/10.1080/15434303.2011.627521

WEF. (2017). The Global Human Capital Report 2017: Preparing for the future of work. World Economic Forum (Vol. 0). https://doi.org/ISBN 978-1-944835-10-1

Wu, J. R. W. (2012). GEPT and English language teaching and testing in Taiwan. Language Assessment Quarterly, 9(1), 11-25. https://doi.org/10.1080/15434303.2011.553251

Website:

http://stptrisakti.ac.id/sejarah/ retrieved at 15 August 2019 